Check for updates

Cite this: New J. Chem., 2018, 42, 13308

Received 1st March 2018, Accepted 11th June 2018

DOI: $10.1039 / c 8 n j 01020 j$

rsc.li/njc

\section{Design of functionalized $\beta$-ketoenole derivatives as efficient fluorescent dyes for detection of amyloid fibrils $\dagger$}

\author{
Vladyslava Kovalska, (D)*a Svitlana Chernii, ${ }^{\text {ab }}$ Mykhaylo Losytskyy, ${ }^{\text {bc }}$ \\ Iryna Tretyakova, ${ }^{\text {b }}$ Yan Dovbii, ${ }^{\mathrm{b}}$ Alexandr Gorski, ${ }^{\mathrm{d}}$ Victor Chernii, ${ }^{\mathrm{b}}$ \\ Rafal Czerwieniec*e and Sergiy Yarmoluk ${ }^{a}$
}

\begin{abstract}
The self-association of proteins into insoluble filamentous aggregates - amyloid fibrils - is associated with a range of protein deposition disorders. With the aim of developing fluorescent probes sensitive to amyloid aggregates, a new series of derivatives of (2Z,5Z,7E)-6-hydroxy-2-(alkylamino)-8-arylocta-2,5,7trien-4-one dyes was synthesized. These dyes are less sensitive to native amyloidogenic proteins, such as insulin or lysozyme, while they have the ability to exhibit a pronounced fluorescence response in the presence of amyloid fibrils of these proteins depending on the structure of the dye tail groups. The dyes associated with the fibrils show green-yellow emission (495-540 nm) and rather large Stokes shift values $(68-125 \mathrm{~nm})$. Upon binding to the fibrils, the fluorescence quantum yields of the dyes could increase by a hundred times up to $0.18-0.47$, and the fluorescence intensity decay time strongly enhances up to 0.9-1.3 ns. These features make ketoenoles attractive as probes for the detection of amyloid fibrils; besides, the efficiency of these dyes for real-time monitoring of the kinetics of protein aggregation is shown. The best sensing properties were shown by dyes 2 and 9 bearing short amino tail groups (correspondingly 2-methoxyethyl and 2-hydroxyethyl) and a 4-substituted phenyl moiety at the other end of the ketoenole backbone.
\end{abstract}

\section{Introduction}

Amyloid fibrils are insoluble protein aggregates that can be formed by different proteins and polypeptides but share a common structure - they consist of $\beta$-pleated filaments twisted together. ${ }^{1}$ Amyloid aggregation is associated with a range of protein deposition disorders; ${ }^{2}$ the reduction of the amount of such aggregates is one of the strategies for developing drugs against neurodegenerative disorders and amyloidoses. Besides their role in pathological processes, amyloid fibrils fulfill important biological functions in cells. ${ }^{3,4}$ For example, curli fibrils ${ }^{5}$ have adhesive properties

\footnotetext{
${ }^{a}$ Institute of Molecular Biology and Genetics NASU, 150 Zabolotnogo St., 03143 Kyiv, Ukraine. E-mail: v.kovalska@gmail.com

${ }^{b}$ V.I. Vernadskii Institute of General and Inorganic Chemistry NASU, 32/34 Palladin Av., 03080 Kyiv, Ukraine

${ }^{c}$ Taras Shevchenko National University of Kyiv, Volodymyrska Str., 64/13, Kyiv-01601, Ukraine

${ }^{d}$ Institute of Physical Chemistry, Polish Academy of Sciences, Kasprzaka 44/52, Warsaw, Poland

${ }^{e}$ Institut für Physikalische und Theoretische Chemie, Universitätsstr. 31, 93053, Regensburg, Germany. E-mail: rafal.czerwieniec@chemie.uni-regensburg.de $\dagger$ Electronic supplementary information (ESI) available. CCDC 1580057 (3) and 1580058 (5). For ESI and crystallographic data in CIF or other electronic format see DOI: $10.1039 / \mathrm{c} 8 \mathrm{nj} 01020 \mathrm{j}$
}

and are involved in the formation of E. coli biofilms. Functional amyloids are involved in melanin synthesis in mammalian melanosomes $^{6}$ and human peptide hormone storage. ${ }^{7}$ In addition, amyloid fibrils are widely studied as templates or building blocks ${ }^{8}$ in bionanomaterials science as components of biomembranes, ${ }^{9}$ biosensors, ${ }^{10}$ and hydrogels for cell culture and for drug delivery. ${ }^{11}$

A range of methods, in particular, circular dichroism spectroscopy, X-ray diffraction, and atomic force microscopy, ${ }^{12-14}$ are used to monitor the self-aggregation of proteins into fibrils.

Besides, amyloid aggregation can be detected by fluorescencebased methods, using dyes sensitive to beta-pleated motifs. ${ }^{3}$ These dyes are simple and inexpensive tools for the prompt detection of fibrils, real-time monitoring of amyloid aggregation kinetics and they are applied in the search for aggregation inhibitors. For visualization of intracellular and intercellular amyloid inclusions (for example, neurofibrillary tangles and senile plaques), fluorescence microscopy is used. ${ }^{15,16}$ Several classes of fluorescent compounds, for instance, naphthalenes, ${ }^{17}$ oligothiophenes, ${ }^{18}$ and curcumin derivatives, ${ }^{19}$ were shown to provide a response upon interaction with fibrils and thus could be useful for fibril detection. Previously, we have reported mono and trimethine cyanine dyes ${ }^{20,21}$ as highly efficient 
amyloid-sensitive probes, which exhibit a strong fluorescent response upon binding to fibrils. Besides, styrylpyridinium dyes $^{22}$ have also shown the ability to fluorescently sense insulin amyloid fibrils. The commonly used dye for the detection and visualization of amyloid aggregates is Thioflavin $\mathrm{T}$, a derivative of the $\mathrm{N}$-methylated benzothiazolium ion. ${ }^{23}$ The fluorescence emission of the Thioflavin $\mathrm{T}$ dye is used for monitoring the fibrillation kinetics and in the study of the prevention of amyloid formation by anti-amyloidogenic compounds. ${ }^{24}$ Another widely known amyloid-sensitive dye, Congo Red, has been used for the detection and visualization of amyloid fibrils in histological specimen materials, for example, histological sections showing apple-green birefringence in polarized light. ${ }^{25}$

Recently, we have discovered $\beta$-ketoenoles as a new class of dyes possessing fluorescence sensitivity to amyloid fibrils. ${ }^{26}$ These compounds are able to increase their fluorescence intensity by dozens of times upon interaction with fibrillar proteins while demonstrating a relatively weak response in the presence of native ones. They bind to fibrils with high binding constant values of about $2 \times 10^{5} \mathrm{M}^{-1}$. Among the advantages of these compounds, the large Stokes shift values (about $100 \mathrm{~nm}$ or more) should be mentioned. It was shown that variation of the aminoalkyl substituent in the $\beta$-ketoenole molecule could strongly affect its amyloid sensing abilities. ${ }^{26}$

Herein, we report a new series of $(2 Z, 5 Z, 7 E)$-6-hydroxy-2(alkylamino)-8-arylocta-2,5,7-trien-4-one dyes with variations of tail amino substituents and aryl moieties (Scheme 1) and study them as fluorescent sensors for amyloid fibrils of proteins. The spectral-luminescent properties of the compounds as well as those in the presence of the proteins insulin and lysozyme in the native and fibrillar form are characterized. The relation between the chemical nature of the substituents in the dye molecule and efficiency of its sensing properties is analyzed. The obtained results suggest that the designed ketoenole derivatives are efficient tools for the detection of amyloid fibrils and the study of protein aggregation.

\section{Materials and methods}

\section{Synthesis and characterization of the dyes}

General procedure. (E)-4-Hydroxy-6-methyl-3-(3-arylacryloyl)$2 \mathrm{H}$-pyran-2-one ( $5 \mathrm{mmol}$ ) was added to $5 \mathrm{ml}$ of dimethylformamide (DMF) and the mixture was heated to $130{ }^{\circ} \mathrm{C}$. A small excess amount $(5.5 \mathrm{mmol})$ of the respective aliphatic amine was added to this solution and left for 3-5 min until the release of carbon dioxide ceased. A change in the color of the reaction mixture from yellow to red was observed. After cooling, the reaction mixture was precipitated with water $(15 \mathrm{ml})$. The resulting solid was filtered, washed with water $(3 \times 10 \mathrm{ml})$ and crystallized from EtOH or a DMF-EtOH mixture ( $7: 3 \mathrm{vol}: \mathrm{vol})$. The crystals were collected by vacuum filtration and washed with EtOH $(2 \times 10 \mathrm{ml})$ and water $(2 \times 10 \mathrm{ml})$, and dried. The crystals of compounds $\mathbf{3}$ and $\mathbf{5}$ obtained in this way were suitable for X-ray studies (Scheme 2).

Molecular structures were confirmed by means of ${ }^{1} \mathrm{H}$ NMR spectroscopy, elemental analysis, and (for compounds 3 and 5) $\mathrm{X}$-ray diffractometry.

1. (2E,5Z,7E)-2-(Dodecylamino)-6-hydroxy-8-(4-propoxyphenyl)octa-2,5,7-trien-4-one. Yield: 55\%. M.p.: $87-90{ }^{\circ} \mathrm{C}$. IR $\mathrm{cm}^{-1}$. (cryst. powd.): 3374(br), 2955(w), 2911(w), 2847(w), 1635(w), 1612(w), 1573(s), 1545(m), 1504(w), 1465(w), 1413(w), 1305(m), 1284(w), 1245(m), 1194(w), 1176(w), 1147(w), 1106(w), 1075(w), 1046(w), 1021(w), 974(w), 966(m), 948(w), 881(w), 824(m), 812(w), 806(w), 796(w), 765(w), 742(w), 721(w), 713(w), 543(w), 516(w), 496(w), 460(w), 421(w). ${ }^{1} \mathrm{H}$ NMR (300 MHz, chloroform- $d$ ) $\delta 15.08$ $(\mathrm{s}, 1 \mathrm{H}), 10.78,10.28(\mathrm{t}+\mathrm{t}, 1 \mathrm{H}), 7.54,7.24(\mathrm{~d}+\mathrm{d}, J=16.1 \mathrm{~Hz}$, $1 \mathrm{H}), 7.43,7.34(\mathrm{~d}+\mathrm{d}, J=8.7 \mathrm{~Hz}, 2 \mathrm{H}), 6.90-6.72(\mathrm{~m}, 2 \mathrm{H}), 6.66,6.22$ $(\mathrm{d}+\mathrm{d}, J=15.8 \mathrm{~Hz}, 1 \mathrm{H}), 5.15,4.70(\mathrm{~s}+\mathrm{s}, 1 \mathrm{H}), 4.95,3.53(\mathrm{~s}+\mathrm{s}, 1 \mathrm{H})$, 3.87 (td, $J=6.5,4.1 \mathrm{~Hz}, 2 \mathrm{H}), 3.17$ (dq, $J=10.7,6.7 \mathrm{~Hz}, 2 \mathrm{H}$ ), 2.29-2.05 (m, 2H), 1.90, 1.86 ( $\mathrm{s}+\mathrm{s}, 3 \mathrm{H}), 1.81-1.66(\mathrm{~m}, 2 \mathrm{H}), 1.53$ $(\mathrm{d}, J=6.7 \mathrm{~Hz}, 2 \mathrm{H}), 1.41-1.13(\mathrm{~m}, 16 \mathrm{H}), 0.97(\mathrm{t}, J=7.4,1.1 \mathrm{~Hz}, 3 \mathrm{H})$, $0.81(\mathrm{t}, J=6.5 \mathrm{~Hz}, 3 \mathrm{H})$. Found (\%): C, 76.50; H, 9.91; N, 3.12. Anal. calcd (\%) for $\mathrm{C}_{29} \mathrm{H}_{45} \mathrm{NO}_{3}$ : C, 76.44; H, 9.95; N, 3.07; O, 10.53.

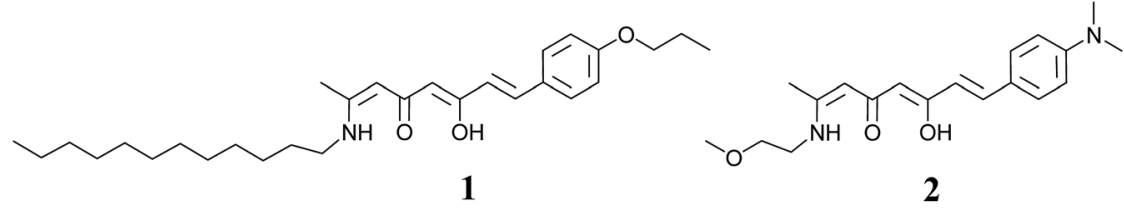

1

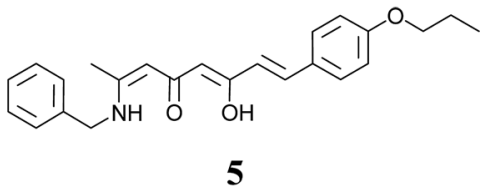

4

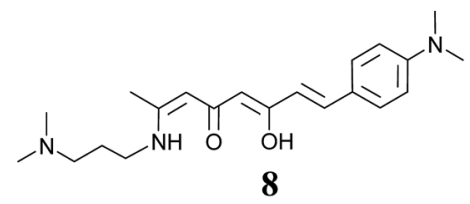

8

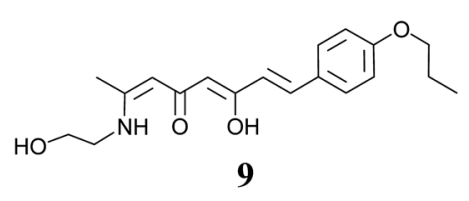

9

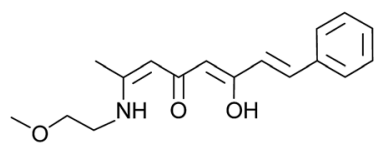

3

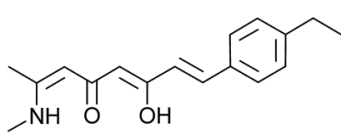

6

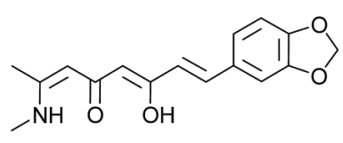

7

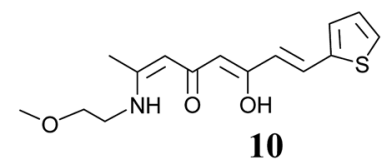

Scheme 1 Formulas of $\beta$-ketoenole dyes. 


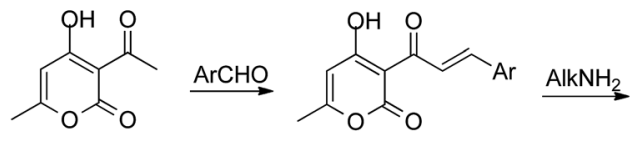

$A$

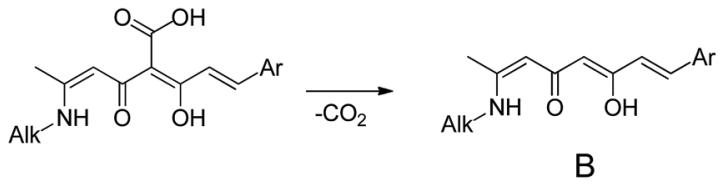

Scheme 2 Synthesis of (2Z,5Z,7E)-6-hydroxy-2-(alkylamino)-8-arylocta-2,5,7-trien-4-one compounds.

2. (2E,5Z,7E)-8-(4-(Dimethylamino)phenyl)-6-hydroxy-2-(2methoxyethylamino)octa-2,5,7-trien-4-one. Yield: 64\%. M.p.: 118-121 ${ }^{\circ}$ C. IR $\mathrm{cm}^{-1}$ (cryst. powd.): 3359(w), 3195(w), 2923(w), 2851(w), 1635(w), 1605(m), 1558(s), 1418(m), 1366(m), 1303(m), 1230(w), 1186(w), 1146(m), 1122(m), 973(w), 937(w), 856(w), 817(w), 728(w), 650(w), 558(w), 517(w), 495(w), 434(w). ${ }^{1} \mathrm{H}$ NMR (300 MHz, chloroform- $d$ ) $\delta 15.20(\mathrm{~s}, 1 \mathrm{H}), 10.89,10.34$ $(\mathrm{t}+\mathrm{t}, J=5.0 \mathrm{~Hz}, 1 \mathrm{H}), 7.45,7.38(\mathrm{~d}+\mathrm{d}, J=8.9 \mathrm{~Hz}, 2 \mathrm{H}), 7.59,7.31$ $(\mathrm{d}+\mathrm{d}, J=15.7 \mathrm{~Hz}, 1 \mathrm{H}), 6.67(\mathrm{~d}, J=3.0 \mathrm{~Hz}, 2 \mathrm{H}), 6.63,6.24(\mathrm{~d}+\mathrm{d}$, $J=15.7 \mathrm{~Hz}, 1 \mathrm{H}), 5.21,4.78(\mathrm{~s}+\mathrm{s}, 1 \mathrm{H}), 5.07,3.59(\mathrm{~s}+\mathrm{s}, 1 \mathrm{H})$, 3.57-3.41 (m, 4H), 3.40, $3.37(\mathrm{~s}+\mathrm{s}, 3 \mathrm{H}), 3.02,2.99(\mathrm{~s}+\mathrm{s}, 6 \mathrm{H})$, 1.98, $1.94(\mathrm{~s}+\mathrm{s}, 3 \mathrm{H})$. Found (\%): C, 69.10; H, 7.87; N, 8.42. Anal. calcd (\%) for $\mathrm{C}_{19} \mathrm{H}_{26} \mathrm{~N}_{2} \mathrm{O}_{3}: \mathrm{C}, 69.06 ; \mathrm{H}, 7.93 ; \mathrm{N}, 8.48 ; \mathrm{O}, 14.53$.

3. (2E,5Z,7E)-6-Hydroxy-2-(2-methoxyethylamino)-8-phenylocta2,5,7-trien-4-one. Yield: $45 \%$. M.p.: $99-102{ }^{\circ} \mathrm{C}$. IR $\mathrm{cm}^{-1}$ (cryst. powd.): 3058(w), 2983(w), 2925(w), 2882(w), 2828(w), 1644(w), 1564(s), 1417(m), 1305(m), 1235(w), 1193(w), 1152(w), 1125(m), 1077(w), 1034(w), 969(m), 936(m), 859(w), 806(m), 753(w), 725(w), 692(w), 586(w), 559(w), 546(w), 491(w), 464(w). ${ }^{1} \mathrm{H}$ NMR $(400 \mathrm{MHz}$, chloroform- $d$ ) $\delta 15.06(\mathrm{~s}, 1 \mathrm{H}), 10.89,10.45(\mathrm{~s}+\mathrm{s}, 1 \mathrm{H}), 7.72-7.21$ $(\mathrm{m}, 6 \mathrm{H}), 6.85,6.42(\mathrm{~d}+\mathrm{d}, J=15.9 \mathrm{~Hz}, 1 \mathrm{H}), 5.26,4.81(\mathrm{~s}, 1 \mathrm{H})$, $5.05,3.62(\mathrm{~s}+\mathrm{s}, 1 \mathrm{H}), 3.54(\mathrm{t}, J=5.1 \mathrm{~Hz}, 2 \mathrm{H}), 3.51-3.41(\mathrm{~m}, 2 \mathrm{H})$, 3.40, $3.36(\mathrm{~s}+\mathrm{s}, 3 \mathrm{H}), 1.99,1.95(\mathrm{~s}+\mathrm{s}, 3 \mathrm{H})$. Found (\%): C, 71.12; $\mathrm{H}, 7.34 ; \mathrm{N}, 4.82$. Anal. calcd (\%) for $\mathrm{C}_{17} \mathrm{H}_{21} \mathrm{NO}_{3}$ : C, 71.06; $\mathrm{H}, 7.37 ; \mathrm{N}, 4.87 ; \mathrm{O}, 16.70$.

4. $(2 E, 5 Z, 7 E)-8-(B e n z o[d][1,3]$ dioxol-5-yl)-2-(3-(dimethylamino)propylamino)-6-hydroxyocta-2,5,7-trien-4-one. Yield: 45\% M.P.: 98-100 ${ }^{\circ}$ C. IR $\mathrm{cm}^{-1}$ (cryst. powd.): 3071(w), 2945(w), 2816(w), 2766(w), 1640(w), 1603(m), 1566(s), 1516(w), 1487(w), 1433(m), 1354(w), 1293(m), 1255(m), 1147(m), 1106(w), 1034(m), 966(w), 939(w), 850(w), 811(w), 725(w), 490(w), 425(w). ${ }^{1} \mathrm{H}$ NMR (400 MHz, chloroform- $d) \delta 15.14(\mathrm{~s}, 1 \mathrm{H}), 10.85,10.38(\mathrm{t}+\mathrm{t}, 1 \mathrm{H}), 7.55,7.26$ $(\mathrm{d}+\mathrm{d}, J=15.6 \mathrm{~Hz}, 1 \mathrm{H}), 7.12-6.89(\mathrm{~m}, 2 \mathrm{H}), 6.85-6.73(\mathrm{~m}, 1 \mathrm{H})$, 6.67, $6.24(\mathrm{~d}+\mathrm{d}, J=15.8 \mathrm{~Hz}, 1 \mathrm{H}), 6.00,5.97(\mathrm{~s}+\mathrm{s}, 2 \mathrm{H}), 5.22,4.77$ $(\mathrm{s}+\mathrm{s}, 1 \mathrm{H}), 5.02,3.58(\mathrm{~s}+\mathrm{s}, 1 \mathrm{H}), 3.43-3.19(\mathrm{~m}, 2 \mathrm{H}), 2.56-2.37(\mathrm{~m}$, $2 \mathrm{H}), 2.31,2.27(\mathrm{~s}+\mathrm{s}, 6 \mathrm{H}), 1.98,1.95(\mathrm{~s}+\mathrm{s}, 3 \mathrm{H}), 1.90-1.71(\mathrm{~m}, 2 \mathrm{H})$. Found (\%): C, 67.05; H, 7.36; N, 7.78. Anal. calcd (\%) for $\mathrm{C}_{20} \mathrm{H}_{26} \mathrm{~N}_{2} \mathrm{O}_{4}$ : C, 67.02; H, 7.31; N, 7.82; O, 17.85 .

5. (2E,5Z,7E)-2-(Benzylamino)-6-hydroxy-8-(4-propoxyphenyl)octa-2,5,7-trien-4-one. Yield: $70 \%$. M.p.: $165-168{ }^{\circ} \mathrm{C}$. IR cm $\mathrm{cm}^{-1}$ (cryst. powd.): 3389(br), 2966(w), 2936(w), 2872(w), 1634(w), 1606(m), 1578(s), 1543(s), 1424(w), 1301(m), 1249(m), 1175(w), 1154(w), 1091(w), 1046(w), 1018(w), 972(w), 952(w), 825(w), 804(w), 755(w), 727(w), 703(w), 563(w), 405(m). ${ }^{1} \mathrm{H} \quad \mathrm{NMR}$ (300 MHz, chloroform- $d$ ) $\delta 15.12(\mathrm{~s}, 1 \mathrm{H}), 11.15,10.68(\mathrm{t}, J=$ $6.1 \mathrm{~Hz}, 1 \mathrm{H}), 7.69-7.14(\mathrm{~m}, 8 \mathrm{H}), 6.96-6.82(\mathrm{~m}, 2 \mathrm{H}), 6.73,6.30$ $(\mathrm{d}+\mathrm{d}, J=15.8 \mathrm{~Hz}, 1 \mathrm{H}), 5.26,4.86(\mathrm{~s}+\mathrm{s}, 1 \mathrm{H}), 4.50,4.46(\mathrm{~d}+\mathrm{d}$, $J=6.3 \mathrm{~Hz}, 2 \mathrm{H}), 4.03-3.87(\mathrm{~m}, 2 \mathrm{H}), 5.12,3.63,(\mathrm{~s}+\mathrm{s}, 1 \mathrm{H})$, 1.97, $1.94(\mathrm{~s}+\mathrm{s}, 3 \mathrm{H}), 1.89-1.71(\mathrm{~m}, 2 \mathrm{H}), 1.04(\mathrm{t}, J=7.4 \mathrm{~Hz}, 3 \mathrm{H})$.
Found (\%): C, 76.39; H, 7.24; N, 3.67. Anal. calcd (\%) for $\mathrm{C}_{24} \mathrm{H}_{27} \mathrm{NO}_{3}$ : C, 76.36; H, 7.21; N, 3.71; O, 12.72.

6. (2E,5Z,7E)-8-(4-Ethylphenyl)-6-hydroxy-2-(methylamino)octa2,5,7-trien-4-one. Yield: 70\%. M.p.: $149-151{ }^{\circ} \mathrm{C}$. IR $\mathrm{cm}^{-1}$ (cryst. powd.): 3365(br), 3034(w), 2969(w), 2932(w), 1617(m), 1572(s), 1547(s), 1515(w), 1444(w), 1412(m), 1377(w), 1313(m), 1281(w), 1193(w), 1143(m), 1083(w), 980(w), 969(w), 941(w), 867(w), 828(w), 704(w), 657(w), 449(w). ${ }^{1} \mathrm{H}$ NMR (300 MHz, chloroform-d) $\delta 15.08$ $(\mathrm{s}, 1 \mathrm{H}), 10.76,10.27(\mathrm{t}+\mathrm{t}, 1 \mathrm{H}), 7.63,7.34(\mathrm{~d}+\mathrm{d}, J=15.9 \mathrm{~Hz}, 1 \mathrm{H})$, 7.53-7.13 (m, 4H), 6.81, 6.39 (d + d, $J=15.8 \mathrm{~Hz}, 1 \mathrm{H}), 5.25,4.82$ $(\mathrm{s}+\mathrm{s}, 1 \mathrm{H}), 5.06,3.61(\mathrm{~s}+\mathrm{s}, 1 \mathrm{H}), 2.98,2.94(\mathrm{~d}+\mathrm{d}, J=5.3 \mathrm{~Hz}, 3 \mathrm{H})$, 2.73-2.57 (m, 2H), 1.98, $1.93(\mathrm{~s}+\mathrm{s}, 3 \mathrm{H}), 1.23(\mathrm{t}, J=7.6 \mathrm{~Hz}, 3 \mathrm{H})$. Found (\%): C, 75.20; H, 7.77; N, 5.12. Anal. calcd (\%) for $\mathrm{C}_{17} \mathrm{H}_{21} \mathrm{NO}_{2}$ : C, 75.25; H, 7.80; N, 5.16; O, 11.79.

7. $(2 E, 5 Z, 7 E)-8-(B e n z o[d][1,3]$ dioxol-5-yl)-6-hydroxy-2-(methylamino)octa-2,5,7-trien-4-one. Yield: 52\%. M.p.: 152-155 ${ }^{\circ} \mathrm{C}$. IR $\mathrm{cm}^{-1}$ (cryst. powd.): 3200(w), 2899(w), 1607(m), 1574(s), 1547(s), 1488(s), 1447(s), 1407(m), 1316(w), 1289(w), 1257(s), 1193(w), 1139(w), 1103(w), 1075(w), 1034(m), 957(m), 934(m), 798(s), 721(m), 671(w), 594(w), 558(w), 512(w), 490(w), 430(w). ${ }^{1} \mathrm{H}$ NMR (300 MHz, chloroform-d) $\delta 15.09$ (s, 1H), 10.77, 10.23 (t, t, 1H), 7.56, 7.26 (d, d, $J=15.7 \mathrm{~Hz}, 1 \mathrm{H}), 7.11-6.90(\mathrm{~m}, 2 \mathrm{H}), 6.86-6.75(\mathrm{~m}$, $1 \mathrm{H}), 6.68,6.25$ (d, d, $J=15.7 \mathrm{~Hz}, 1 \mathrm{H}), 6.00,5.97$ (s, s, 2H), 5.22, 4.81 (s, s, 1H), 3.59, 5.05 (s, s, 1H), 2.98, 2.94 (d, d, J = 5.3 Hz, 3H), 1.97, 1.93 (s, s, 3H). Found (\%): C, 66.93; H, 5.94; N, 4.84. Anal. calcd (\%) for $\mathrm{C}_{16} \mathrm{H}_{17} \mathrm{NO}_{4}$ : C, 66.89; H, 5.96; N, 4.88; O, 22.27.

8. (2E,5Z,7E)-8-(4-(Dimethylamino)phenyl)-2-(3-(dimethylamino)propylamino)-6-hydroxyocta-2,5,7-trien-4-one. Yield: $72 \%$. M.p.: $117-120{ }^{\circ}$ C. IR cm ${ }^{-1}$ (cryst. powd.): 3042(w), 2943(w), 2860(w), 2815(w), 2766(w), 1637(w), 1607(m), 1565(s), 1516(m), 1417(m), 1357(m), 1307(m), 1286(m), 1227(w), 1186(w), 1144(m), 1102(w), 967(w), 947(w), 814(w), 727(w), 516(w), 495(w), 457(w). ${ }^{1} \mathrm{H}$ NMR (300 MHz, chloroform- $d$ ) $\delta 15.27$ (s, 1H), 10.85, 10.30 $(\mathrm{t}+\mathrm{t}, J=5.8 \mathrm{~Hz}, 1 \mathrm{H}), 7.59(\mathrm{~d}, J=15.9 \mathrm{~Hz}, 1 \mathrm{H}), 7.46,7.38(\mathrm{~d}+\mathrm{d}$, $J=8.8 \mathrm{~Hz}, 2 \mathrm{H}), 7.59,7.30(\mathrm{~d}+\mathrm{d}, J=15.8 \mathrm{~Hz}, 1 \mathrm{H}), 6.73-6.54$ $(\mathrm{m}, 2 \mathrm{H}), 6.65,6.23(\mathrm{~d}+\mathrm{d}, J=15.7 \mathrm{~Hz}, 1 \mathrm{H}), 5.20,4.75(\mathrm{~s}+\mathrm{s}, 1 \mathrm{H})$, 5.04, $3.58(\mathrm{~s}+\mathrm{s}, 1 \mathrm{H}), 3.41-3.22(\mathrm{~m}, 2 \mathrm{H}), 3.02,2.99(\mathrm{~s}+\mathrm{s}, 6 \mathrm{H})$, 2.44-2.29 (m, 2H), 2.24, $2.21(\mathrm{~s}+\mathrm{s}, 6 \mathrm{H}), 1.97,1.93(\mathrm{~s}, \mathrm{~s}, 3 \mathrm{H})$, 1.87-1.63 (m, 2H). Found (\%): C, 70.59; H, 8.78; N, 11.72. Anal. calcd (\%) for $\mathrm{C}_{21} \mathrm{H}_{31} \mathrm{~N}_{3} \mathrm{O}_{2}$ : C, 70.55; H, 8.74; N, 11.75; O, 8.95.

9. (2E,5Z,7E)-6-Hydroxy-2-(2-hydroxyethylamino)-8-(4-propoxyphenyl)octa-2,5,7-trien-4-one. Yield: 38\%. M.p.: 87-90 ${ }^{\circ} \mathrm{C}$. IR cm ${ }^{-1}$ (cryst. powd.): 3383(br), 3052(w), 2964(w), 2935(w), 2875(w), 1639(w), 1606(m), 1566(s), 1511(m), 1422(w), 1303(m), 1252(m), 1175(w), 1150(w), 1115(w), 1064(w), 973(w), 934(w), 868(w), 826(w), 808(w), 753(w), 729(w), 698(w), 667(w), 637(w), 518(w), 447(w). ${ }^{1} \mathrm{H}$ NMR (300 MHz, chloroform- $d$ ) $\delta 14.96(\mathrm{~s}, 1 \mathrm{H})$, 10.86, $10.32(\mathrm{t}+\mathrm{t}, 1 \mathrm{H}), 7.53,7.25(\mathrm{~d}+\mathrm{d}, J=15.8 \mathrm{~Hz}, 1 \mathrm{H})$, $7.43,7.34(\mathrm{~d}+\mathrm{d}, J=8.7 \mathrm{~Hz}, 2 \mathrm{H}), 6.89-6.75(\mathrm{~m}, 2 \mathrm{H}), 6.64,6.22$ 
$(\mathrm{d}+\mathrm{d}, J=15.8 \mathrm{~Hz}, 1 \mathrm{H}), 5.16,4.75(\mathrm{~s}+\mathrm{s}, 1 \mathrm{H}), 3.95-3.81(\mathrm{~m}, 2 \mathrm{H})$, 3.78-3.60 (m, 2H), 5.00, 3.54, (s + s, 1H), 3.47-3.21 (m, 2H), 2.22 (s, 1H), 1.93, $1.90(\mathrm{~s}+\mathrm{s}, 3 \mathrm{H}), 1.74(\mathrm{dt}, J=7.2 \mathrm{~Hz}, 2 \mathrm{H}), 0.97$ (t, $J=7.4 \mathrm{~Hz}, 3 \mathrm{H}$ ). Found (\%): C, 68.81; H, 7.57; N, 4.19. Anal. calcd (\%) for $\mathrm{C}_{19} \mathrm{H}_{25} \mathrm{NO}_{4}$ : C, 68.86; $\mathrm{H}, 7.60 ; \mathrm{N}, 4.23 ; \mathrm{O}, 19.31$.

10. $(2 E, 5 Z, 7 E)-6$-Hydroxy-2-(2-methoxyethylamino)-8-(thiophen2-yl)octa-2,5,7-trien-4-one. Yield: $45 \%$. M.p.: $86-87{ }^{\circ} \mathrm{C}$. IR cm $\mathrm{cm}^{-1}$ (cryst. powd.): 3108(w), 2985(w), 2925(w), 2881(w), 2830(w), 2735(w), 1635(w), 1609(m), 1567(s), 1514(m), 1419(m), 1359(w), 1299(m), 1197(w), 1151(w), 1123(m), 1084(w), 1042(w), 975(w), 954(w), 938(w), 853(w), 823(w), 804(w), 702(w), 659(w), 589(w), 551(w), 488(w), 460(w). ${ }^{1} \mathrm{H}$ NMR (300 MHz, chloroform-d) $\delta 15.07$ $(\mathrm{s}, 1 \mathrm{H}), 10.89,10.44(\mathrm{t}+\mathrm{t}, 1 \mathrm{H}), 7.76,7.46(\mathrm{~d}+\mathrm{d}, J=15.5 \mathrm{~Hz}, 1 \mathrm{H})$, 7.40-6.99 (m, 3H), 6.64, $6.22(\mathrm{~d}+\mathrm{d}, J=15.5 \mathrm{~Hz}, 1 \mathrm{H}), 5.23,4.80$ $(\mathrm{s}+\mathrm{s}, 1 \mathrm{H}), 5.04,3.58(\mathrm{~s}+\mathrm{s}, 1 \mathrm{H}), 3.57-3.42(\mathrm{~m}, 4 \mathrm{H}), 3.40,3.37$ $(\mathrm{s}+\mathrm{s}, 3 \mathrm{H}), 1.99,1.95(\mathrm{~s}+\mathrm{s}, 3 \mathrm{H})$. Found (\%): C, 61.46; H, 6.57; N, 4.73. Anal. calcd. (\%) for $\mathrm{C}_{15} \mathrm{H}_{19} \mathrm{NO}_{3} \mathrm{~S}: \mathrm{C}, 61.41 ; \mathrm{H}, 6.53 ; \mathrm{N}, 4.77$; O, 16.36; S, 10.93.

X-ray analysis. 3. (2E,5Z,7E)-6-Hydroxy-2-(2-methoxyethylamino)8-phenylocta-2,5,7-trien-4-one. A suitable crystal $(0.16 \times 0.15 \times$ $0.08 \mathrm{~mm}$ ) was selected and mounted on a MITIGEN holder on a SuperNova Atlas diffractometer equipped with an Oxford Cryosystems CryoStream 700 low-temperature apparatus. During data collection, the crystal was kept at $T=123 \mathrm{~K}$. Data were collected using $\mathrm{CuK} \alpha$ radiation. Cell parameters were retrieved and refined using CrysAlisPro software (Agilent Technologies UK Ltd) on 7013 reflections, $42 \%$ of the observed reflections. Data reduction was performed using the CrysAlisPro software (Agilent Technologies UK Ltd), which corrects for Lorentz polarisation. The final completeness is 100.00 out to 73.410 in $\Theta$. The absorption coefficient $(\mu)$ of this material is 0.662 and the minimum and maximum transmissions are 0.980 and 0.991 . The structure was solved in the space group $P 2{ }_{1} 2_{1} 2_{1}$ (No. 19) using the OLEX2 computer program ${ }^{27}$ and refined by least squares using ShelXL. ${ }^{28}$ All non-hydrogen atoms were refined anisotropically. The hydrogen atom positions were calculated geometrically and refined using the riding model.

Crystal data. $\mathrm{C}_{17} \mathrm{H}_{21} \mathrm{NO}_{3}, M_{\mathrm{r}}=287.35$, orthorhombic, $P 2{ }_{1} 2_{1} 2_{1}$ (No. 19), $a=8.0221(2) \AA, b=8.5085(2) \AA, c=23.2424(4) \AA$, $\alpha=\beta=\gamma=90^{\circ}, V=1586.43(6) \AA^{3}, T=123.00(10) \mathrm{K}, Z=4, Z^{\prime}=1$, $\mu(\mathrm{CuK} \alpha)=0.662,16588$ reflections measured, 3165 unique $\left(R_{\text {int }}=0.0401\right)$, which were used in all calculations. The final $\mathrm{w} R_{2}$ was 0.0784 (all data) and $R_{1}$ was $0.0316(I>2(I))$.

Further crystal and refinement data are provided in Table 1.

5. (2E,5Z,7E)-2-(Benzylamino)-6-hydroxy-8-(4-propoxyphenyl)octa-2,5,7-trien-4-one. A suitable crystal $(0.20 \times 0.16 \times 0.08 \mathrm{~mm})$ was selected and mounted on a MITIGEN holder on a SuperNova Atlas diffractometer equipped with an Oxford Cryosystems CryoStream 700 low-temperature apparatus. During data collection, the crystal was kept at $T=123 \mathrm{~K}$. Data were collected using $\mathrm{CuK} \alpha$ radiation. Cell parameters were retrieved and refined using CrysAlisPro (Agilent) on 32994 reflections, 38\% of the observed reflections. Data reduction was performed using the CrysAlisPro software (Agilent Technologies UK Ltd), which corrects for Lorentz polarisation. The final completeness is 100.00 out to 73.556 in $\Theta$. The absorption coefficient $(\mu)$ of this
Table 1 Crystal and refinement data for compounds $\mathbf{3}$ and $\mathbf{5}$

\begin{tabular}{|c|c|c|}
\hline Compound & 3 & 5 \\
\hline Formula & $\mathrm{C}_{17} \mathrm{H}_{21} \mathrm{NO}_{3}$ & $\mathrm{C}_{48} \mathrm{H}_{54} \mathrm{~N}_{2} \mathrm{O}_{6}$ \\
\hline$D_{\text {calc. }} / \mathrm{g} \mathrm{cm}^{-3}$ & 1.203 & 1.243 \\
\hline$\mu / \mathrm{mm}^{-1}$ & 0.662 & 0.647 \\
\hline Formula weight & 287.35 & 754.93 \\
\hline Colour & Clear yellow & Clear yellow \\
\hline Shape & Prism & Plate \\
\hline Max size/mm & 0.16 & 0.20 \\
\hline Mid size/mm & 0.15 & 0.16 \\
\hline Min size/mm & 0.08 & 0.08 \\
\hline$T / \mathrm{K}$ & $123.00(10)$ & $123.00(10)$ \\
\hline Crystal system & Orthorhombic & Monoclinic \\
\hline Flack parameter & $0.1(2)$ & \\
\hline Hooft parameter & $0.16(9)$ & \\
\hline Space group & $P 2_{1} 2_{1} 2_{1}$ & $P 2_{1} / n$ \\
\hline$a / \AA$ & $8.0221(2)$ & $22.0779(2)$ \\
\hline$b / \AA$ & $8.5085(2)$ & $7.22350(10)$ \\
\hline$c / \AA$ & $23.2424(4)$ & $25.3699(3)$ \\
\hline$\alpha /^{\circ}$ & 90 & 90 \\
\hline$\beta /^{\circ}$ & 90 & $94.5190(10)$ \\
\hline$\gamma /^{\circ}$ & 90 & 90 \\
\hline$V / \AA^{3}$ & $1586.43(6)$ & $4033.41(8)$ \\
\hline$Z$ & 4 & 4 \\
\hline$Z^{\prime}$ & 1 & 1 \\
\hline$\Theta_{\min } /^{\circ}$ & 3.804 & 3.495 \\
\hline$\Theta_{\max } /^{\circ}$ & 73.410 & 73.556 \\
\hline Measured refl. & 16588 & 86784 \\
\hline Independent refl. & 3165 & 8076 \\
\hline Reflections used & 2903 & 6959 \\
\hline$R_{\text {int }}$ & 0.0401 & 0.0409 \\
\hline Parameters & 212 & 511 \\
\hline Restraints & 0 & 0 \\
\hline Largest peak & 0.151 & 0.230 \\
\hline Deepest hole & -0.166 & -0.207 \\
\hline GooF & 1.044 & 1.024 \\
\hline $\mathrm{w} R_{2}$ (all data) & 0.0784 & 0.0961 \\
\hline $\mathrm{w} R_{2}$ & 0.0751 & 0.0908 \\
\hline$R_{1}$ (all data) & 0.0367 & 0.0416 \\
\hline$R_{1}$ & 0.0316 & 0.0345 \\
\hline
\end{tabular}

material is 0.647 at this wavelength $(\lambda=1.54184)$ and the minimum and maximum transmissions are 0.989 and 0.995 .

The structure was solved in the space group $P 2_{1} / n$ (No. 14) by Intrinsic Phasing using the ShelXT structure solution program and refined by least squares using version 2014/7 of ShelXL. All non-hydrogen atoms were refined anisotropically. The hydrogen atom positions were calculated geometrically and refined using the riding model.

Crystal data. $\mathrm{C}_{48} \mathrm{H}_{54} \mathrm{~N}_{2} \mathrm{O}_{6}, M_{\mathrm{r}}=754.93$, monoclinic, $P 2_{1} / n$ (No. 14), $a=22.0779(2) \AA, b=7.22350(10) \AA, c=25.3699(3) \AA$, $\beta=94.5190(10)^{\circ}, \alpha=\gamma=90^{\circ}, V=4033.41(8) \AA^{3}, T=123.00(10) \mathrm{K}$, $Z=4, Z^{\prime}=1, \mu(\mathrm{CuK} \alpha)=0.647,86784$ reflections measured, 8076 unique $\left(R_{\text {int }}=0.0409\right)$, which were used in all calculations. The final $\mathrm{w} R_{2}$ was 0.0961 (all data) and $R_{1}$ was $0.0345(I>2(I))$.

Further crystal and refinement data are provided in Table 1 . The crystallographic data for compounds $\mathbf{3}$ and $\mathbf{5}$ have been deposited at the Cambridge Crystallographic Data Centre (CCDC) with deposition numbers 1580057 (3) and 1580058 (5), respectively. $\dagger$

\section{Insulin and lysozyme fibril preparation}

Human insulin (Sigma-Aldrich) was dissolved at $340 \mu \mathrm{M}$ $\left(2 \mathrm{mg} \mathrm{ml} \mathrm{m}^{-1}\right.$ ) concentration in a $0.1 \mathrm{M}$ water solution of $\mathrm{HCl}$ (pH 2). Fibrils were formed by incubating the insulin solution 
in a thermo-mixer incubator at $65{ }^{\circ} \mathrm{C}$ for $5 \mathrm{~h}$. Hen egg lysozyme (Sigma-Aldrich) was dissolved at $1 \mathrm{mM}\left(14.5 \mathrm{mg} \mathrm{ml}^{-1}\right)$ concentration in a $0.1 \mathrm{M}$ water solution of $\mathrm{HCl}(\mathrm{pH} 2)$. Fibrillar aggregates were formed by incubating the protein solution in a thermo-mixer incubator at $65{ }^{\circ} \mathrm{C}$ for about $24 \mathrm{~h}$. The 7519 dye fluorescence assay was used to monitor amyloid aggregation. The presence and the shape of aggregates were confirmed by scanning electron microscopy.

\section{Preparation of dye solutions}

Stock solutions of dyes were obtained by dissolving the dyes at $2 \mathrm{mM}$ concentration in DMSO. Working solutions of free dyes were prepared by diluting dye stock solutions in $50 \mathrm{mM}$ Tris-HCl buffer ( $\mathrm{pH}$ 7.9) to a concentration of $2 \mu \mathrm{M}$. The working solutions of the dyes in the presence of native or fibrillar proteins were prepared by adding an aliquot of the dye stock solution and an aliquot of the native or fibrillar protein solution into $50 \mathrm{mM}$ Tris-HCl buffer ( $\mathrm{pH}$ 7.9).

\section{Spectral measurements}

Absorption spectra were recorded on a Cary 300 BIO UV-Vis spectrophotometer at a dye concentration of $10 \mu \mathrm{M}$ in DMSO and in $50 \mathrm{mM}$ Tris-HCl buffer ( $\mathrm{pH}$ 7.9). Fluorescence excitation and emission spectra were recorded on a Cary Eclipse fluorescence spectrophotometer (Varian); concentrations of the dye, insulin and lysozyme were $2,3.4$ and $8 \mu \mathrm{M}$, respectively. The wavelength of the fluorescence excitation was set to be equal to the wavelength of the maximum of the fluorescence excitation band of the dye in the corresponding solution. The excitation and emission slit size was maintained at $5 \mathrm{~nm}$ during all the measurements using a Cary Eclipse system. All spectral measurements were performed in standard quartz cuvettes $(1 \times 1 \mathrm{~cm})$ at room temperature. The emission quantum yields for dyes bound to insulin fibrils were determined directly using a Hamamatsu photonic multichannel analyser C10027 equipped with a Spectralon ${ }^{\circledR}$ integrating sphere. Since the sphere cannot measure precisely the values of quantum yield below $2 \%$, we have also determined the quantum yield values of the four free dyes $(2 \mu \mathrm{M})$ with the help of a Fluorolog C9920-02 system by a relative method using Coumarin 307 solution in methanol as the reference (quantum yield value $0.92^{29}$ ). All measurements were performed at ambient temperature.

\section{Time-resolved fluorescence}

The time-resolved measurements of $\beta$-ketoenole dye fluorescence in complexes with fibrillar insulin and lysozyme were made using a home-built setup, consisting of a PicoQuant pulsed diode laser, a Digikröm CM112 monochromator working in the subtractive mode, a Hamamatsu 3809 MCP photomultiplier, and a Becker\&Hickl SPC-830 time-correlated single-photoncounting module. Excitation was performed at $375 \mathrm{~nm}$. The concentrations used were $20,8.5$ and $20 \mu \mathrm{M}$ for dye, insulin and lysozyme, respectively, and $50 \mathrm{mM}$ Tris- $\mathrm{HCl}$ buffer ( $\mathrm{pH}$ 7.9) was used as the solvent. Measurements were performed in fluorescence quartz cells $(1 \times 1 \mathrm{~cm})$ at room temperature. The average lifetime values $\left(\tau_{\mathrm{AVE}}\right.$; intensity averaged $)$ of the dye/amyloid fibril complexes were calculated using the equation: $\tau=\tau_{1} \times$ $B_{1}+\tau_{2} \times B_{2}$, where $B_{1}$ and $B_{2}$ are relative amplitudes determined by $B_{1}=A_{1} \times \tau_{1} /\left(A_{1} \times \tau_{1}+A_{2} \times \tau_{2}\right)$ and $B_{2}=A_{2} \times \tau_{2} /$ $\left(A_{1} \times \tau_{1}+A_{2} \times \tau_{2}\right)$; fluorescence lifetimes $\left(\tau_{1}, \tau_{2}\right)$ and their amplitudes $\left(A_{1}, A_{2}\right)$ were obtained by fitting the fluorescence intensity decays of the dye in the presence of fibrillar proteins to the minimum number of exponential terms that produced randomly distributed residuals.

The fluorescence intensity decay time $(\tau)$ and the radiative excited state lifetime $\left(\tau_{\mathrm{r}}\right)$ of the free dye were calculated for four selected dyes from the QY of the free dye $\left(\mathrm{QY}_{\text {free }}\right)$ and the dye in the presence of the fibrils $\left(\mathrm{QY}_{\text {bound }}\right)$ as well as $\tau_{\mathrm{AVE}}$ (see above) under an assumption that $\tau_{\mathrm{r}}$ does not change noticeably in the presence of fibrils according to $\tau=\tau_{\mathrm{AVE}} \times\left(\mathrm{QY}_{\text {free }} / \mathrm{QY}_{\text {bound }}\right)$ and $\tau_{\mathrm{r}}=\tau_{\mathrm{AVE}} / \mathrm{QY}$ bound.

\section{Evaluation of aggregation kinetics}

The reaction of insulin fibrillation was performed as described above. Aliquots of the reaction mixture were withdrawn from each tube at about 90, 150, 240 and 300 minutes after the reaction was started and added to the $2 \mu \mathrm{M}$ solution in $50 \mathrm{mM}$ Tris-HCl buffer ( $\mathrm{pH}$ 7.9) of amyloid sensitive dye Thioflavin $\mathrm{T}$ (used as the reference dye) and the investigated $\beta$-ketoenole dye 2.

\section{Results and discussion}

\section{Syntheses and molecular structures}

$\beta$-Ketoenoles presented here were obtained by a two-step procedure (Scheme 1). In the first step, the corresponding (E)-4-hydroxy-6methyl-3-(3-arylacryloyl)-2H-pyran-2-one derivatives were obtained by condensation of dehydroacetic acid with aromatic aldehydes, as described in ref. 30 (Scheme 1, intermediate A). In the second step, reaction of these intermediates with aliphatic amines resulted in the opening of the pyran ring, decarboxylation and formation of (2Z,5Z,7E)-6-hydroxy-2-(alkylamino)-8-arylocta-2,5,7-trien-4-one dyes (Scheme 1, compound B). The mechanism of this reaction was studied in detail in ref. 30 and 31 . In this work, we proposed a modification to our earlier used synthetic protocol. ${ }^{26}$ It was shown that an increase of the reagent concentration, the temperature of the reaction mixture and the shortening of the reaction time leads to higher yields of the target products.

Compounds $\mathbf{3}$ and $\mathbf{5}$ crystallize as yellow plates in the monoclinic crystal system (space group $P 2_{1} / n$ ). Molecules of 3 and 5 display a planar arrangement of the polyene chain of the ketoenol fragment conjugated with the aromatic ring at position 8, phenyl and propoxyphenyl in $\mathbf{3}$ and 5, respectively (Fig. 1). The planar configuration of the ketoenole group is further stabilized by $\mathrm{H}$-bonds between the 6-hydroxy and 4-keto functions. Similarly, H-bonding interactions between the 2-amino and 4-keto groups are present.

\section{Fluorescence properties of dyes in the presence of native and fibrillar proteins}

To examine the fluorescence sensitivity of the novel dyes towards protein fibrils, the fluorescence emission and excitation spectra 


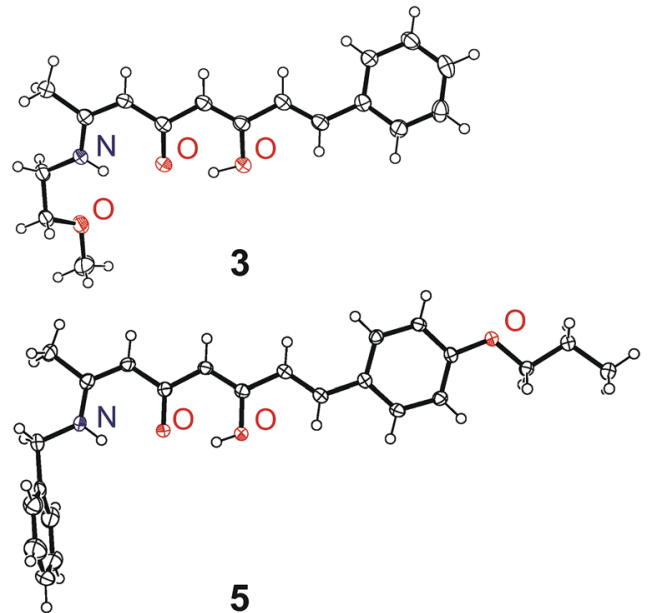

Fig. 1 Perspective drawings of molecules $\mathbf{3}$ (top) and $\mathbf{5}$ (bottom) obtained from $X$-ray diffraction studies. Thermal ellipses are shown at $50 \%$ probability.

were measured for the free dyes in buffer and after the addition of native or fibrillar insulin and lysozyme. The main characteristics of the fluorescence spectra are presented in Table 2, and the spectra of dye 2 are shown in Fig. 2. The emission spectra were recorded upon excitation at the maxima of the excitation spectra.

Free dyes display very low fluorescence intensity with the emission maxima in the range of $496-535 \mathrm{~nm}$. Values of the shift between the excitation and emission maxima are large (from $86 \mathrm{~nm}$ for 6 to $140 \mathrm{~nm}$ for 1 ), which is typical for $\beta$-ketoenoles and is in agreement with previously reported results. ${ }^{26}$

Addition of native insulin (globular protein that mostly contains alpha-helical motifs in its structure) causes minor changes in the excitation and emission spectra. The emission maxima shift unessentially to the long- or short-wavelength region by up to $15 \mathrm{~nm}$ (Table 2). The emission intensity is almost unaffected. For most compounds and Thioflavin $\mathrm{T}$, the fluorescence quantum yield of both free dyes (buffer solution) and dyes in solutions containing native insulin is very small (less than $2 \%$ ). Only for compounds 1, 4, 5, and 6 did the measured quantum yield exceed the threshold of our quantum yield measurement setup, being $c a$. $2 \%$, which amounted to $8.5 \%, 3.6 \%, 2.7 \%$, and $3.7 \%$, respectively (ESI, $\dagger$ Table S1).

The fluorescence characteristics of the studied $\beta$-ketoenoles in the presence of fibrillar insulin $\left(I^{\mathrm{F}}\right)$ are presented in Table 2. The addition of $\beta$-ketoenoles to these protein aggregates resulted in a strong increase of dye fluorescence intensity as compared to that in buffer solutions $\left(I_{0}\right)$ and solutions containing native protein $\left(I^{\mathrm{N}}\right)$. The most prominent increase (the value of $I^{\mathrm{F}} / I_{0}$ ratio equal to 295) is observed for dye $\mathbf{9}$, which bears a 2-hydroxyethylamino tail group and a para-substituted phenyl moiety. The essential enhancement of the fluorescence intensity in the presence of fibrillar insulin also took place for dye 2 bearing a 2-methoxyethylamino tail group and a para-substituted phenyl moiety, for the dyes 4 and 7 with alkylamino tail groups on one end and 5-benzo[d][1,3]dioxole on the other end of the molecule, as well as for dye 10 . The values of $I^{\mathrm{F}} / I_{0}$ ratio for dyes $2,4,7$, and 10 are equal to $55,66,45$ and 95 respectively, which is comparable with or higher than the corresponding value for Thioflavin $\mathrm{T}$ $\left(I^{\mathrm{F}} / I_{0}=55\right)$. Besides, dye 2 also shows the highest value of emission intensity in the presence of fibrillar insulin (Table 2). For the dyes with para-substituted phenyl moieties (6 and 8), the fluorescence intensity increase is less pronounced and is equal to about 25 for both compounds, when referred to the respective buffer solutions (Table 2).

It is remarked that the dye-fibril complexes of compounds 2 and 9 show very high fluorescence quantum yields of 0.47 and 0.38 , respectively, which are higher than the quantum yields found for any other $\beta$-ketoenole analogues so far. ${ }^{26}$ The quantum yield values of the studied ketoenole dyes bound to fibrils were comparable with or higher (up to more than two times for dye 2) than those of Thioflavin $\mathrm{T}$ (measured as $20 \%$ ). The fluorescence quantum yield of Thioflavin $\mathrm{T}$ incorporated into fibrils was reported to be $43 \% .^{32} \mathrm{~A}$ small deviation of the QY by a factor of two as reported in the cited work and as measured by us may be explained by distinct inhomogeneity and the difference in the structure of the fibril populations. It should be mentioned that the measured quantum yield values might be slightly underestimated due to absorption by the unbound dye form still present in solution.

Table 2 Fluorescence properties of $\beta$-ketoenole dyes in the presence of native and fibrillar insulin

\begin{tabular}{|c|c|c|c|c|c|c|c|}
\hline \multirow[b]{2}{*}{ Name } & \multicolumn{2}{|l|}{ Buffer } & \multicolumn{2}{|c|}{ With native insulin } & \multicolumn{3}{|c|}{ With fibrillar insulin } \\
\hline & $\lambda_{\mathrm{em}}\left(\lambda_{\mathrm{ex}}\right), \mathrm{nm}$ & $I_{0}$, a.u. & $\lambda_{\mathrm{em}}\left(\lambda_{\mathrm{ex}}\right), \mathrm{nm}$ & $I^{\mathrm{N}}$, a.u. & $\lambda_{\mathrm{em}}\left(\lambda_{\mathrm{ex}}\right), \mathrm{nm}$ & $I^{F}$, a.u. & QY \\
\hline 1 & $521(381)$ & 7.2 & $521(382)$ & 8 & $507(382)$ & 10 & 0.04 \\
\hline 2 & $535(417)$ & 3.1 & $533(417)$ & 3.2 & $540(458)$ & 172 & 0.47 \\
\hline 3 & $503(400)$ & 0.7 & $498(401)$ & 0.9 & $500(414)$ & 18 & 0.28 \\
\hline 4 & $507(400)$ & 0.9 & $492(400)$ & 1.7 & 495 (421) & 59 & 0.20 \\
\hline 5 & $512(408)$ & 29 & $510(400)$ & 23 & $500(418)$ & 80 & 0.28 \\
\hline 6 & $496(410)$ & 2 & $496(410)$ & 4 & $497(417)$ & 50 & 0.24 \\
\hline 7 & $505(414)$ & 0.8 & $514(414)$ & 0.9 & $500(419)$ & 36 & 0.26 \\
\hline 8 & $529(405)$ & 3.1 & $524(408)$ & 3.4 & $552(456)$ & 76 & 0.30 \\
\hline 9 & $508(400)$ & 0.2 & 499 (406) & 0.2 & $495(427)$ & 59 & 0.38 \\
\hline 10 & $512(414)$ & 0.2 & $514(414)$ & 0.2 & $514(424)$ & 19 & 0.18 \\
\hline Thioflavin $\mathrm{T}$ & $526(444)$ & 2.2 & $520(442)$ & 2.5 & $483(445)$ & 120 & 0.20 \\
\hline
\end{tabular}

$\lambda_{\mathrm{em}}-$ maximum of emission spectrum. $\lambda_{\mathrm{ex}}-$ lowest energy maximum of excitation spectrum. $I_{0}, I^{\mathrm{N}}, I^{\mathrm{F}}-$ emission intensity measured at $\lambda_{\mathrm{em}}$ upon excitation at $\lambda_{\mathrm{ex}}$ in buffer solution without protein, in the presence of native insulin, and in the presence of fibrillar insulin, respectively. $\mathrm{QY}$ - fluorescence quantum yield. 
A

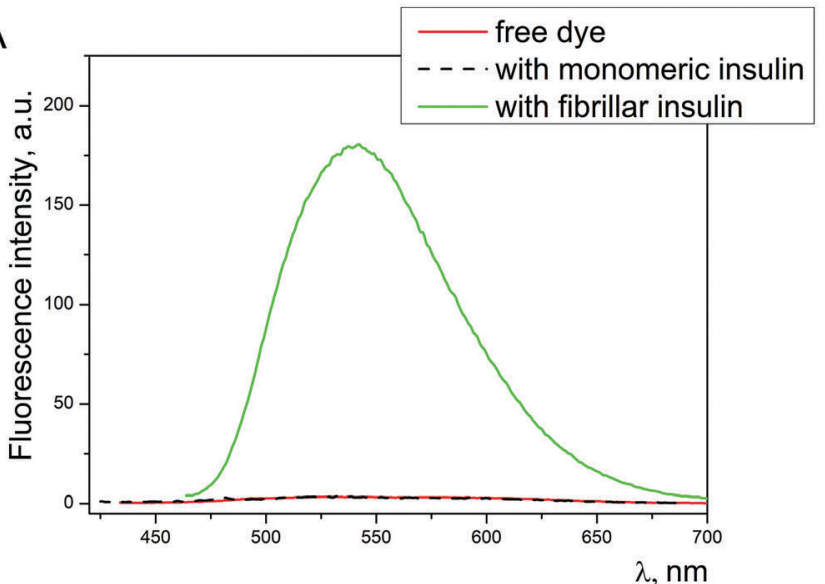

B

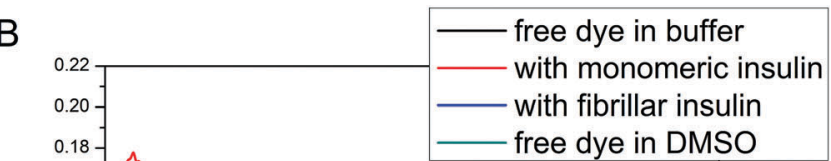

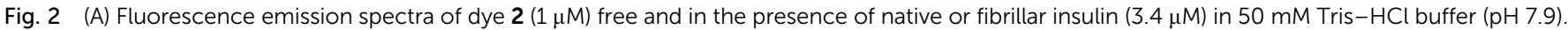

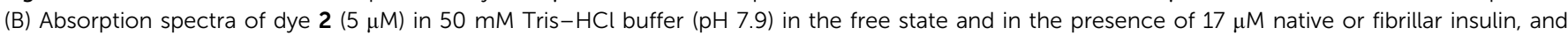
in DMSO.

For each compound, the Stokes shifts determined from the emission and excitation spectrum maxima are significantly smaller in the presence of fibrillar insulin than for the free dye buffer solution (68-125 $\mathrm{nm}$ vs. 86-140 $\mathrm{nm}$ respectively). This difference along with the distinctly higher emission quantum yields indicates the greater rigidity of the sites occupied by dye molecules in the fibrillar protein as compared to the solution and the closest environment of the dye in the presence of non-fibrillar proteins. At the same time, these Stokes shifts are still large enough from the point of view of the convenient use of the dyes as fluorescent probes. It should be mentioned that the Stokes shift value of Thioflavin $\mathrm{T}$ decreases from 82 to $38 \mathrm{~nm}$ upon the addition of insulin fibrils, which is much less as compared to the studied dyes.

For dyes 2, 8, 9 and Thioflavin $\mathrm{T}$ that show a high increase of emission intensity in the presence of fibrillar insulin, the sensitivity towards fibrils formed by another amyloidogenic protein lysozyme was studied. To evaluate the impact of the substituent in the phenyl moiety on the amyloid-sensitive properties of the dye, compound 3 that is a structural analogue of highly efficient dye 2 , with a non-substituted phenyl group, was also characterized with fibrillar lysozyme.

Based on a model of the ketoenoles binding to fibrils, the placement of the dye molecule into the groove formed by the beta-pleated sheets of the protein was assumed. ${ }^{26}$ At the same time, amyloid fibrils formed by insulin and lysozyme have a distinct morphology. Lysozyme consists of a single polypeptide chain, which is involved in the fibril core formation, while insulin chain A is suggested to be located at the outer surface of the fibril and involved in lateral aggregation. ${ }^{33,34}$ Thus, comparing the sensitivity of the dyes to the fibrils with a difference in the structure of beta-pleated motifs will allow estimating the "versatility" of $\beta$-ketoenoles as amyloid-sensitive probes.

The studied dyes have close positions of excitation and emission maxima and the same shape of spectra in the presence of both fibrillar proteins. The fluorescence responses of $\beta$-ketoenole dyes $\mathbf{2}$ and $\mathbf{8}$ to fibrillar insulin are higher as compared to those

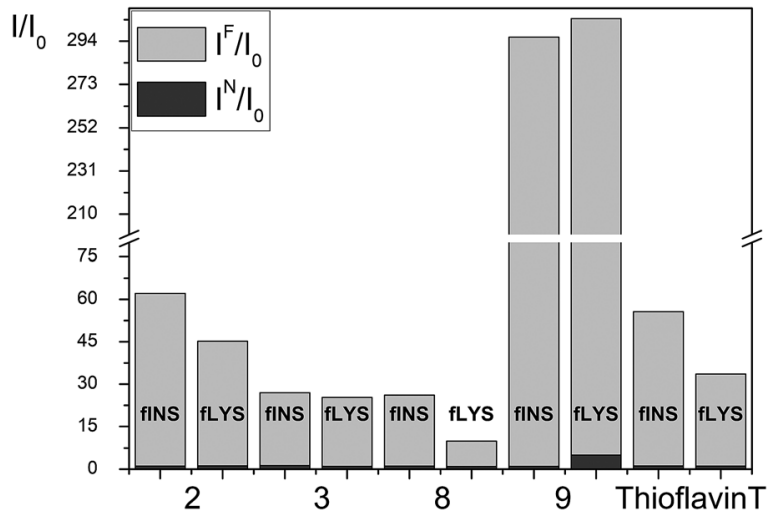

Fig. 3 Diagram showing sensitivity of the dye luminescence to fibrillar and native proteins, where $I^{F} / I_{0}$ - ratio of emission intensity of the dye in the presence of fibrillar insulin (fINS) or lysozyme (fLYS) to that of the free dye; $/ \mathrm{N} / I_{0}$ - ratio of emission intensity of the dye in the presence of native insulin or lysozyme to that of the free dye.

of fibrillar lysozyme (Fig. 3) for the used concentrations, while for the dyes $\mathbf{3}$ and $\mathbf{9}$, they are about equal. The most pronounced fluorescence response in the presence of fibrillar lysozyme is shown by the dye 9; though this dye also demonstrates the highest response to native lysozyme.

$\beta$-Ketoenole dye molecules exhibit long fragments containing conjugated double bonds that render a planar shape of the molecules (Fig. 1). Thus, intercalating interactions with nucleic acids can be expected. However, $\beta$-ketoenoles possess no response to the presence of DNA (our data show that the emission intensity of dye 2 in the presence of $60 \mu \mathrm{M}$ b.p. of salmon tastes dsDNA equals the emission intensity of free dye; separate work will be published containing these data). This could be explained by their low affinity to nucleic acids due to the neutral charge of the dye molecules, since nucleic acids strongly prefer binding with positively charged molecules. This property does "increase the selectivity" of ketoenole dyes to amyloid fibrils and is considered as an advantage of these dyes for histological experiments. 
Thus, we conclude that the new $\beta$-ketoenoles represent potent amyloid fibril probes that exhibit a significant increase of emission intensity amounting to dozens of times when bound to fibrillar proteins and a negligible response to the native proteins and nucleic acids. The emission spectra of these dyes are characterized by large Stokes shifts required for practical use as luminescent probes.

The sensing ability of the dyes towards amyloid fibrils is strongly influenced by terminal groups, both the amino and aromatic moieties. The response is significantly decreased by long aliphatic chains and large aryl groups (dyes 1 and 5). This is easily explained in the framework of the model of ketoenoles binding with fibrils via noncovalent interactions with the grooves of fibrillar proteins. In this case, the sterically demanding aliphatic and/or aryl tails hinder the interaction due to the unsuitable shape and size of the dye molecules.

Compounds exhibiting electron donating substituents (amino group, ether group, methylendioxy group) at the terminal benzene moiety conjugated with the backbone double bond system show improved amyloid-sensing properties. For these dyes, in the presence of fibrillar proteins, higher relative emission intensity $\left(I^{\mathrm{F}}\right)$ and higher emission increase as expressed by the $I^{\mathrm{F}} / I^{\mathrm{N}}$ ratios (Fig. 3) are observed. This effect can be rationalized in terms of the different dispersive interactions between the dye and aromatic groups of the protein. Electron-rich aromatic groups (i.e. benzenes with electron donating substituents) tend to engage in stronger $\pi-\pi$ stacking interactions than electron-deficient moieties.

\section{Absorption characteristics of the studied $\beta$-ketoenoles}

Characteristics of the UV-Vis absorption spectra of free ketoenoles in DMSO and aqueous buffer (50 mM Tris-HCl, $\mathrm{pH} 7.9$ ) are presented in Table 3; Fig. 4 shows the absorption spectra of dyes 8 and 9 in these solvents. The spectra in aprotic DMSO have broad bands and moderate extinction coefficients of the main maximum in the range of (3.1-4.4) $\times 10^{4} \mathrm{M}^{-1} \mathrm{~cm}^{-1}$. Their maximum wavelengths are in the range of $400-440 \mathrm{~nm}$; for some of the dyes, the minor short-wavelength bands with

Table 3 Characteristics of UV-Vis absorption spectra of the dyes

\begin{tabular}{|c|c|c|c|c|}
\hline \multirow[b]{2}{*}{ Name } & \multicolumn{2}{|c|}{$\underline{\text { Buffer solution (Tris-HCl pH 7.9) }}$} & \multicolumn{2}{|l|}{ DMSO } \\
\hline & $\lambda_{\max }, \mathrm{nm}$ & $\varepsilon, 10^{4} \mathrm{M}^{-1} \mathrm{~cm}^{-1}$ & $\lambda_{\max }, \mathrm{nm}$ & $\varepsilon, 10^{4} \mathrm{M}^{-1} \mathrm{~cm}^{-1}$ \\
\hline 1 & 380 & 0.8 & 406 & 3.7 \\
\hline \multirow[t]{2}{*}{2} & 318 & 1.3 & 438 & 3.5 \\
\hline & 405 & 1.6 & & \\
\hline \multirow[t]{2}{*}{3} & $316^{*}$ & 2.7 & 401 & 3.7 \\
\hline & 400 & 0.25 & & \\
\hline 4 & 318 & 3.8 & 407 & 3.8 \\
\hline 5 & 401 & 2.8 & 418 & 4.4 \\
\hline \multirow[t]{2}{*}{6} & $318^{*}$ & 2.7 & 401 & 3.8 \\
\hline & 401 & 0.28 & & \\
\hline 7 & 316 & 2.4 & 407 & 5.1 \\
\hline \multirow[t]{2}{*}{8} & $314^{*}$ & 1.7 & 439 & 4.3 \\
\hline & 409 & 2.2 & & \\
\hline 9 & 329 & 2.3 & 404 & 3.3 \\
\hline 10 & 328 & 2.2 & 411 & 3.1 \\
\hline
\end{tabular}

$\lambda_{\max }$ - maxima of UV-Vis absorption spectra, $\mathrm{nm} ; \varepsilon-$ molar extinction coefficient, $\mathrm{M}^{-1} \mathrm{~cm}^{-1}$; * shoulder of the main band.

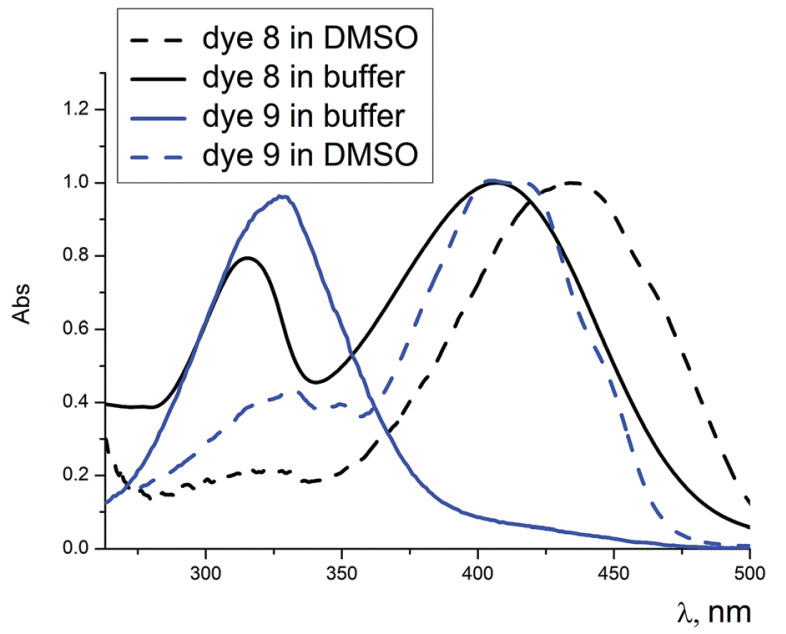

Fig. 4 Normalized absorption spectra of dye $\mathbf{8}$ in DMSO and $50 \mathrm{mM}$ Tris- $\mathrm{HCl}$ buffer and 9 in 50 mM Tris- $\mathrm{HCl}$ buffer and DMSO.

maxima at 322-334 $\mathrm{nm}$ are observed (data not presented). It is suggested that the shape of the spectra and positions of the maxima are influenced by the electron donor properties of substituents in the aryl fragment.

Absorption spectra of the studied dyes in buffer (Table 3) contain bands with the main maximum in one of the regions (315-331 nm or 380-407 nm; and minor maximum in the other one) or in both these regions, which might depend on the dye conformation in buffer. The values of molar extinction coefficient of the main bands of the studied dyes in buffer are close to those in DMSO. The highest value of extinction coefficient (about $3.8 \times 10^{4} \mathrm{M}^{-1} \mathrm{~cm}^{-1}$ ) is observed for dye 4 .

Further, absorption spectra of the dyes with native and fibrillar insulin were obtained. Upon addition of native insulin, the form of the dye spectra does not change (see Fig. 2 for dye 2; for other dyes, data not shown). In the presence of fibrillar insulin, for dyes $2,3,4,6,7,8,9$ and 10, an appearance or an increase of the band at $406-430 \mathrm{~nm}$ is observed (Fig. 5; ESI, $\dagger$ Table S2). The highly effective dye 2 upon addition of the insulin fibrils shifts its absorption band maximum from 406 to $420 \mathrm{~nm}$ and increases the band intensity (Fig. 2B). Such changes could be explained by a dye conformation transition from non-fluorescent unbound form to fluorescent (bound to amyloid fibrils) form. However, such a growth of the longwavelength band is not observed for dye $\mathbf{8}$, which already has two absorption bands in the free state (314 and $409 \mathrm{~nm}$ ).

Furthermore, the long-wavelength absorption bands (406-430 $\mathrm{nm})$ are close to the fluorescence excitation bands (417-458 nm) for dyes bound to insulin fibrils. Thus, it could be supposed that the dye-fibril fluorescent complex absorbs in this region (406-430 nm).

\section{Fluorescence decay time of dye-fibril complexes}

To characterize the complexes formed by the dyes with fibrils, we measured fluorescence decays for $\beta$-ketoenoles 2, 8, 9 (dyes giving strong fluorescence response) and $\mathbf{3}$ in the presence of insulin and lysozyme fibrils. The decays are not monoexponential 


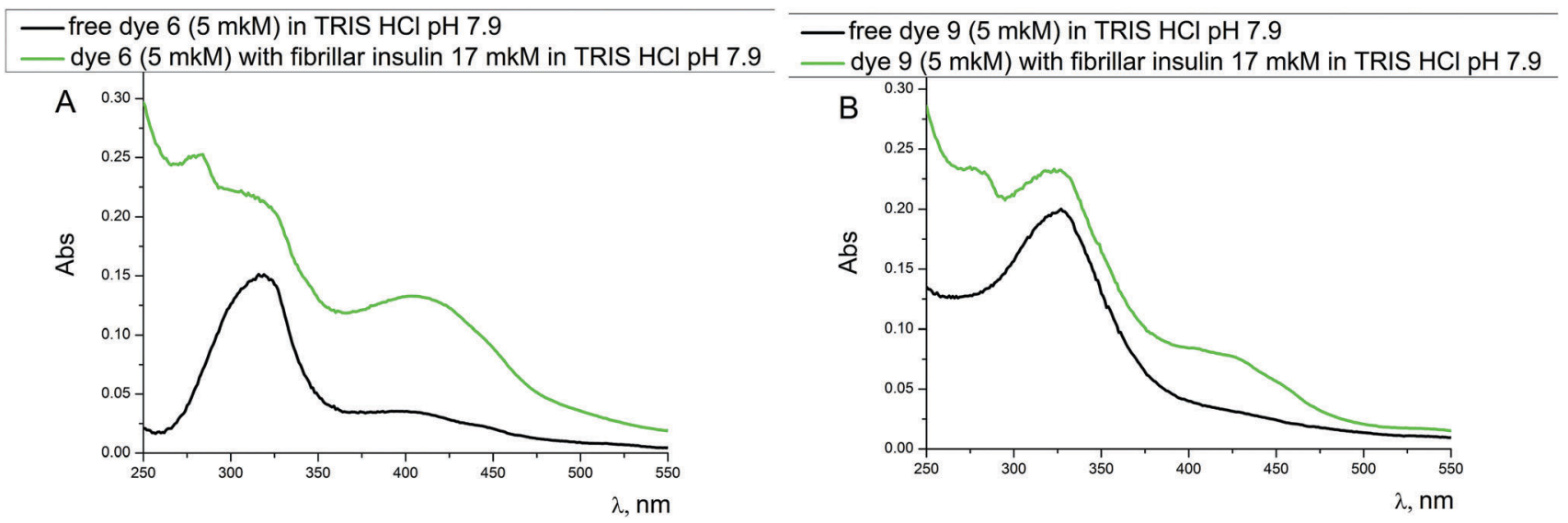

Fig. 5 Absorption spectra of the dyes 6 (A) and 9 (B) in $50 \mathrm{mM}$ Tris $-\mathrm{HCl}$ buffer in free state and in the presence of fibrillar insulin.

Table 4 Characteristics (decay times $\tau_{1}, \tau_{2}$ and relative intensities $B_{1}, B_{2}$ ) of fluorescence intensity decay curves for selected dyes in the presence of fibrillar insulin (fINS) and fibrillar lysozyme (fLYS), and the values of average decay time $\left(\tau_{\text {AVE }}\right)$

\begin{tabular}{lllllll}
\hline Sample & $T_{1}, \mathrm{~ns}$ & $B_{1}$ & $\tau_{2}, \mathrm{~ns}$ & $B_{2}$ & $\tau_{\mathrm{AVE}}, \mathrm{ns}$ & $\chi_{\text {red }}$ \\
\hline Dye 2 $20 \mu \mathrm{M}$ + fINS 8.5 $\mu \mathrm{M}$ & 0.18 & 0.30 & 1.40 & 0.70 & 1.0 & 8.42 \\
Dye 3 $20 \mu \mathrm{M}$ + fINS 8.5 $\mu \mathrm{M}$ & 0.48 & 0.36 & 1.47 & 0.64 & 1.1 & 4.72 \\
Dye 8 $20 \mu \mathrm{M}$ + fINS 8.5 $\mu \mathrm{M}$ & 0.19 & 0.29 & 1.46 & 0.71 & 1.1 & 6.35 \\
Dye 9 $20 \mu \mathrm{M}$ + fINS 8.5 $\mu \mathrm{M}$ & 0.43 & 0.55 & 1.42 & 0.45 & 0.9 & 3.76 \\
\hline
\end{tabular}

Sample $\quad T_{1}$, ns $\quad B_{1} \quad \tau_{2}$, ns $B_{2} \quad \tau_{\text {AVE }}$, ns $\quad \chi_{\text {red }}$

\begin{tabular}{lllllll}
\hline Dye $220 \mu \mathrm{M}+$ fLYS $20 \mu \mathrm{M}$ & 0.11 & 0.22 & 1.46 & 0.78 & 1.2 & 2.09
\end{tabular}
$\begin{array}{lllllll}\text { Dye } 320 \mu \mathrm{M}+\text { fLYS } 20 \mu \mathrm{M} & 0.30 & 0.26 & 1.46 & 0.74 & 1.15 & 1.43\end{array}$

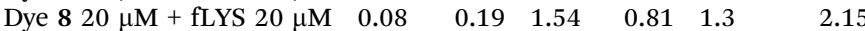

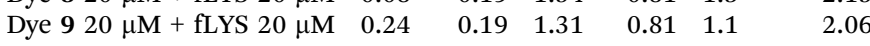

and could be adequately fitted with biexponential decay functions with decay times $\tau_{1}$ (short) and $\tau_{2}$ (long), respectively. The numerical data are listed in the Table 4.

In the presence of fibrillar insulin, the values of $\tau_{1}$ are close for dyes 2 and 8 both containing $4-N, N$-dimethylaminophenyl substituents ( 0.18 and $0.19 \mathrm{~ns}$, respectively); this differs them from the two other dyes with phenyl (3) and 4-propoxyphenyl (9) substituents $\left(\tau_{1}\right.$ values are 0.48 and $0.43 \mathrm{~ns}$, respectively). At the same time, the values of the long decay time $\left(\tau_{2}\right)$ are close for all for dyes (1.40-1.47 ns). The relative intensity $B_{1}$ of the component with the short decay time is smaller than the relative intensity $B_{2}$ of the long decay component in the case of all investigated dyes except 9 . The value of the average decay time $\left(\tau_{\mathrm{AVE}}\right)$ is near for all four studied dyes (between 0.9 and $1.1 \mathrm{~ns}$ ).

As for the dyes in the presence of fibrillar lysozyme, generally, the same tendencies are observed. The values of the short component $\tau_{1}$ for dyes 2 and 8 ( 0.11 and $0.08 \mathrm{ns,}$ respectively) are lower as compared to the $\tau_{1}$ values for dyes 3 and 9 ( 0.30 and $0.24 \mathrm{~ns}$, respectively), while the values of the long component $\tau_{2}$ are close for all four dyes in the presence of lysozyme fibrils (1.31-1.54 ns). The relative intensity $B_{1}$ of the short component is smaller than $B_{2}$ for all four investigated dyes. The values of $\tau_{\mathrm{AVE}}$ are between 1.1 and $1.3 \mathrm{~ns}$. The somewhat higher values of average decay time in the case of fibrillar lysozyme as compared to insulin are due to the lower contribution of the short decay component in the former case. The obtained values of $\tau_{\mathrm{AVE}}$ could be compared with that for Thioflavin $\mathrm{T}$ in complex with $\mathrm{A} \beta(1-42)$ fibrils (up to $0.63 \mathrm{~ns}$ ). ${ }^{35}$

The two-component origin of the fluorescence decay could possibly correspond to two tautomeric forms of the dyes. For related compounds, the existence of a set of tautomeric forms of the ketoenol fragment was established by NMR. ${ }^{36}$ Another possible explanation could be the formation of two kinds of dye-fibril complexes with, e.g., different degrees of rigidity of the dye molecule fixated on the fibril. In any case, since all the studied dyes have similar components of the fluorescence decay in the case of both fibrillar proteins, we could suppose that the origin of these components is the same for all dyes.

Since the values of quantum yield for the free dyes $2,3,8$ and 9 cannot be precisely measured by the sphere, these values were determined by a relative method (see "Materials and Methods" section). For the free dyes $\mathbf{2}$ and $\mathbf{8}$, the values of QY are about $0.5 \%$, while for dyes $\mathbf{3}$ and $\mathbf{9}$, these values are noticeably lower and equal to $0.15 \%$ and $0.04 \%$, respectively (Table 5). Based on the values of $\tau_{\mathrm{AVE}}$ as well as fluorescence quantum yield of the free dyes and dyes in the presence of fibrillar insulin, the average values of excited state lifetime of free dyes were calculated (Table 5) to be of the order of 1.6-18 picoseconds. The lifetime values for the free dyes 2 and 8 (11 and 18 ps, respectively) are much higher as compared to dyes 3 and 9 (1.6 and 3.5 ps, respectively).

In summary, it could be concluded that the presence of fibrillar proteins results in a strong increase in both the fluorescence quantum yield and fluorescence intensity decay time of the studied $\beta$-ketoenole dyes.

\section{Monitoring of fibril formation kinetics}

The emission changes due to binding with beta-pleated motifs permit us to quantify fibril formation. Thus, compound 2 was used for monitoring the kinetics of amyloid aggregation of proteins.

To estimate the applicability of dye 2 (most efficient as reporter among studied $\beta$-ketoenoles) to monitor the kinetics of insulin fibrillation, this dye was applied as a reporter during the aggregation in comparison with Thioflavin $\mathrm{T}$ as a 
Table 5 Photophysical characteristics of selected dyes free and in the presence of fibrillar insulin

\begin{tabular}{|c|c|c|c|c|c|}
\hline \multicolumn{3}{|c|}{ Dye } & \multicolumn{2}{|c|}{ Dye + fibrillar insulin } & \multirow[b]{2}{*}{$\tau_{\mathrm{r}}$, ns (calculated } \\
\hline Dye & QY & $T$, ns (calculated) & QY & $\tau_{\mathrm{AVE}}, \mathrm{ns}$ & \\
\hline 2 & 0.0052 & 0.011 & 0.47 & 1.0 & 2.2 \\
\hline 3 & 0.0004 & 0.0016 & 0.28 & 1.1 & 3.9 \\
\hline 8 & 0.0049 & 0.018 & 0.30 & 1.1 & 3.7 \\
\hline 9 & 0.0015 & 0.0035 & 0.38 & 0.9 & 2.3 \\
\hline
\end{tabular}

QY - fluorescence quantum yield (measured directly for the dyes in the presence of insulin fibrils and by a relative method for the free dyes; see "Materials and Methods" section); $\tau_{\mathrm{AVE}}$ - average decay time of the dye in the presence of insulin fibrils (from Table 4 ); $\tau$ and $\tau_{\mathrm{r}}$ - fluorescence intensity decay time and radiative excited state lifetime of the free dye calculated from QY of the free dye and dye in the presence of the fibrils as well as $\tau_{\mathrm{AVE}}$ under an assumption that $\tau_{\mathrm{r}}$ does not change noticeably in the presence of fibril.

reference dye. ${ }^{37}$ Two main stages of the aggregation reaction, i.e. lag-phase (nucleation) and fibril growth, ${ }^{38}$ are characteristic of amyloid fibril formation. As shown on the kinetics curves (Fig. 6A), both dyes reflect those two stages. The kinetic curve of insulin fibrillation obtained with dye 2 is of a similar shape to that for Thioflavin $\mathrm{T}$ but it has a higher intensity of fluorescence signal. Since dye 2 reflects the passing of protein fibrillation with good efficiency, it could be proposed as a tool for monitoring protein aggregation and using in amyloid-fibril inhibitory assay.

\section{Detection range for dye 2}

To examine the sensitivity of dye 2 to quantify amyloid formations, we have studied the concentration range of the fibrillar insulin detection using this dye. For this, the titration of $2 \mu \mathrm{M}$ dye solution with increasing amounts of fibrils was performed. The lower detection limit was determined as two times the increase of fluorescence intensity upon binding to fibrils and the upper limit was estimated as the concentration where fluorescence intensity approached saturation. The fluorescence intensity of dye 2 upon increasing the insulin concentration increases monotonically in the range of $0.8-100 \mu \mathrm{g} \mathrm{ml} \mathrm{m}^{-1}$ (Fig. 6B), which is higher than that for the amyloid-specific dye Thioflavin $\mathrm{T}\left(0.5-40 \mathrm{mg} \mathrm{ml}^{-1}\right)$.

\section{Conclusions}

A series of new functionalized (2Z,5Z,7E)-6-hydroxy-2-(alkylamino)8-arylocta-2,5,7-trien-4-one compounds was synthesized and studied as probes for fluorescence detection of amyloid aggregates of proteins. The chemical advantages of these dyes are that they are not expensive and the availability of parent compounds together with the cost-effective, rather easy, twostep protocol of their synthesis that does not require the procedure of chromatographic separation.

Depending on the nature of the substituents, these dyes could increase their emission intensity up to dozens of times upon the presence of fibrillar aggregates, while being slightly sensitive to native proteins. Both amino tail substituents and the aryl moiety in the dye molecule determine its amyloid-sensing properties. The electron donating substituents in the benzene moiety (amino group, ether group, methylendioxy group) lead to the increase of the amyloid-sensing properties of the dye.

The studied dyes possess green-yellow emission (495-540 nm) and large (68-125 nm) Stokes shift values. For the most effective compound 2 that bears a 2-methoxyethylamino tail group and para-substituted phenyl moiety, the fluorescence quantum yield upon binding to insulin fibrils reaches $47 \%$ while for the free dye, this value is about $0.5 \%$.

The quantum yield value of dye $\mathbf{2}$ complexed with fibrils is shown as twice that of the commonly used dye Thioflavin $\mathrm{T}$; besides, dye 2 possesses a Stokes shift of about $80 \mathrm{~nm}$ while for Thioflavin $\mathrm{T}$, this value is about $40 \mathrm{~nm}$. Those factors are suggested as advantages of this ketoenole dye. A wide concentration range of insulin fibril detection $\left(0.8-100 \mu \mathrm{g} \mathrm{ml}^{-1}\right)$ and the applicability for real-time monitoring of the kinetics of fibril formation were shown for this dye.
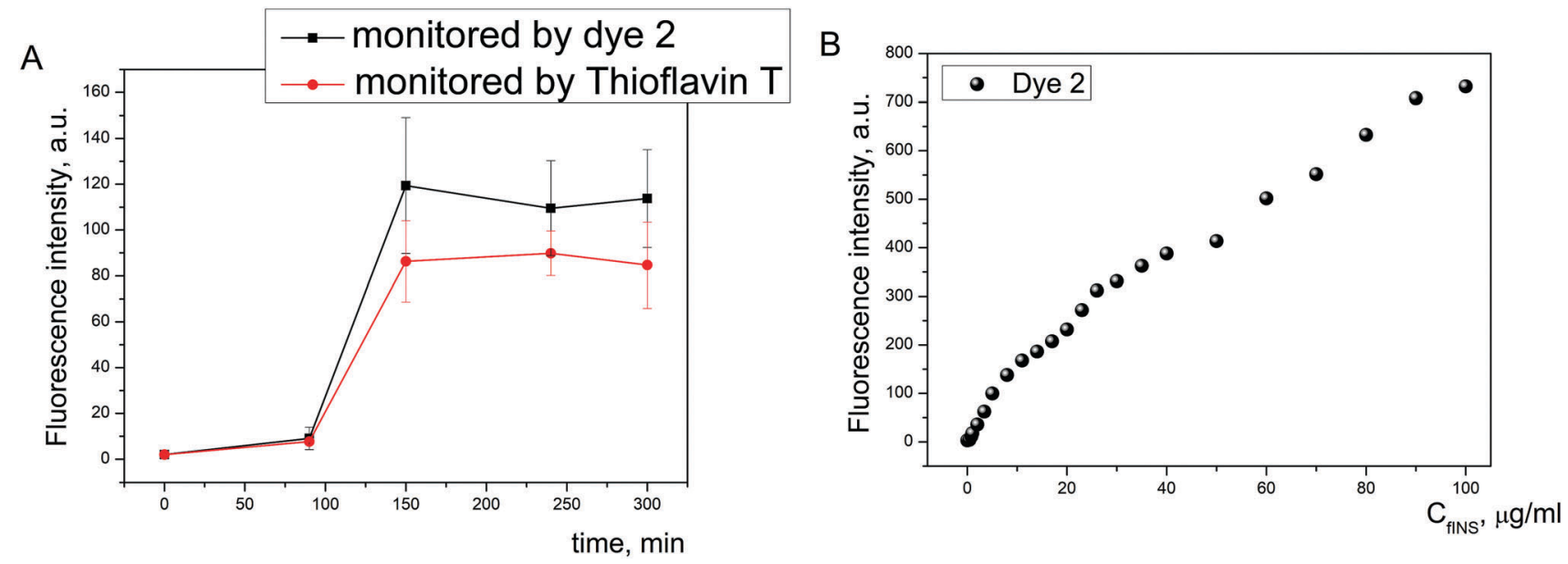

Fig. 6 Kinetics of human insulin fibrillation assessed with fluorescence emission of Thioflavin T and dye 2 using a $2 \mu \mathrm{M}$ dye concentration (A). Titration of dye $2(2 \mu \mathrm{M})$ with fibrillar insulin (concentration range $\left.0.8-100 \mu \mathrm{g} \mathrm{ml}^{-1}\right)(B)$. 
The average values of fluorescence intensity decay time for dyes upon binding to protein fibrils are strongly enhanced and are in the range of $0.9-1.3 \mathrm{~ns}$. The two-component origin of the fluorescence decay is suggested to correspond to two tautomeric forms of the dye or two different mechanisms of dye-fibril binding.

Due to their attractive features, $\beta$-ketoenole dyes are considered as prospective fluorescent tools for amyloid fibril detection, the study of protein aggregation and forming a basis for fluorescence amyloid-inhibitory assay. Besides, they are suggested for further study as stains for visualization methods, particularly fluorescence microscopy.

\section{Conflicts of interest}

There are no conflicts to declare.

\section{Acknowledgements}

This work was supported by the Horizon 2020 MSCA RISE Grant No. 645628, the Polish Ministry of Science and Higher Education Grant No. W77/H2020/2017 and the Targeted Program of Scientific Researches of NAS of Ukraine "New functional compounds and materials of chemical production" 2017-2018, N 8-1. We thank Dr Michael Bodensteiner (Zentrale Analytik; Universität Regensburg) for X-ray measurements.

\section{References}

1 M. Sunde, L. C. Serpell, M. Bartlam, P. E. Fraser, M. B. Pepys and C. C. Blake, J. Mol. Biol., 1997, 273, 729-739.

2 E.-T. Ang, Y.-K. Tai, S.-Q. Lo, R. Seet and T.-W. Soong, Front. Aging Neurosci., 2010, 2-25.

3 M. P. Jackson and E. W. Hewitt, Biomolecules, 2017, 22(7), E71.

4 A. Hewetson, H. Q. Do, C. Myers, A. Muthusubramanian, R. B. Sutton, B. J. Wylie and G. A. Cornwall, Biomolecules, 2017, 7, E46.

5 M. R. Chapman, L. S. Robinson, J. S. Pinkner, R. Roth, J. Heuser, M. Hammar, S. Normark and S. J. Hultgren, Science, 2002, 295, 851-855.

6 D. M. Fowler, A. V. Koulov, W. E. Balch and J. W. Kelly, Trends Biochem. Sci., 2007, 32, 217-224.

7 S. K. Maji, D. Schubert, C. Rivier, S. Lee, J. E. Rivier and R. Riek, PLoS Biol., 2008, 6, 240-252.

8 G. Wei, Z. Su, N. P. Reynolds, P. Arosio, I. W. Hamley, E. Gazitf and R. Mezzenga, Chem. Soc. Rev., 2017, 46, 4661-4708.

9 D. Romero, C. Aguilar, R. Losick and R. Kolter, Proc. Natl. Acad. Sci. U. S. A., 2010, 107, 2230-2234.

10 C. X. Li, J. Adamcik and R. Mezzenga, Nat. Nanotechnol., 2012, 7, 421-427.

11 R. S. Jacob, D. Ghosh, P. K. Singh, S. K. Basu, N. N. Jha, S. Das, P. K. Sukul, S. Patil, S. Sathaye, A. Kumar, A. Chowdhury, S. Malik, S. Sen and S. K. Maji, Biomaterials, 2015, 54, 97-105.

12 T. T. Ding and J. D. Harper, Methods Enzymol., 1999, 309, 510-525.

13 L. C. Serpell, Biochim. Biophys. Acta, 2000, 26, 16-30.
14 G. T. Westermark, K. H. Johnson and P. Westermark, Methods Enzymol., 1999, 309, 3-25.

15 J.-Y. Kim, S. Sahu, Y.-H. Yau, X. Wang, S. G. Shochat, P. H. Nielsen, M. S. Dueholm, D. E. Otzen, J. Lee, M. M. S. D. Santos, J. K. H. Yam, N.-Y. Kang, S.-J. Park, H. Kwon, T. Seviour, L. Yang, M. Givskov and Y.-T. Chang, J. Am. Chem. Soc., 2016, 138, 402-407.

16 S. Navarro and S. Ventura, Biotechnol. J., 2014, 9, 1259-1266.

17 M. S. Celej, E. A. Jares-Erijman and T. M. Jovin, Biophys. J., 2008, 94, 4867-4879.

18 A. Aslund, C. J. Sigurdson, T. Klingstedt, S. Grathwohl, T. Bolmont, D. L. Dickstein, E. Glimsdal, S. Prokop, M. Lindgren, P. Konradsson, D. M. Holtzman, P. R. Hof, F. L. Heppner, S. Gandy, M. Jucker, A. Aguzzi, P. Hammarström and K. P. R. Nilsson, ACS Chem. Biol., 2009, 4, 673-684.

19 J. Sutharsan, M. Dakanali, C. C. Capule, M. A. Haidekker, J. Yang and E. A. Theodorakis, ChemMedChem, 2010, 5, 56-60.

20 M. V. Kuperman, S. V. Chernii and M. Y. Losytskyy, Anal. Biochem., 2015, 484, 9-17.

21 V. B. Kovalska, M. Y. Losytskyy, O. I. Tolmachev, Y. L. Slominskii, G. M. Segers-Nolten, V. Subramaniam and S. M. Yarmoluk, J. Fluoresc., 2012, 22, 1441-1448.

22 D. I. Inshyn, S. V. Chernii, V. B. Kovalska and S. M. Yarmoluk, Biopolym. Cell, 2016, 32, 289-299.

23 M. R. Krebs, E. H. Bromley and A. M. Donald, J. Struct. Biol., 2005, 149, 30-37.

24 S. A. Hudson, H. Ecroyd, T. W. Kee and J. A. Carver, FEBS J., 2009, 276, 5960-5972.

25 A. J. Howie, D. B. Brewer, D. Howell and A. P. Jones, Lab. Invest., 2008, 88, 232-242.

26 V. Kovalska, S. Chernii, M. Losytskyy, Y. Dovbii, I. Tretyakova, R. Czerwieniec, V. Chernii, S. Yarmoluk and S. Volkov, Dyes Pigm., 2016, 132, 274-281.

27 O. V. Dolomanov, L. J. Bourhis, R. J. Gildea, J. A. K. Howard and H. Puschmann, J. Appl. Crystallogr., 2009, 42, 339-341.

28 G. M. Sheldrick, Acta Crystallogr., Sect. C: Struct. Chem., 2015, 71, 3-8.

29 A. V. Deshpande and U. Kumar, J. Fluoresc., 2006, 16, 679-687. 30 N. Aït-Baziz, Y. Rachedi, M. Hamdi, A. Silva, F. Balegroune, R. Thierry and N. Sellier, J. Heterocycl. Chem., 2004, 41, 587-591.

31 D. Chergui, M. Hamdi, M. Baboulene, V. Speziale and A. Lattes, J. Heterocycl. Chem., 1986, 23, 1721-1724.

32 A. I. Sulatskaya, A. A. Maskevich, I. M. Kuznetsova, V. N. Uversky and K. K. Turoverov, PLoS One, 2010, 5, e15385.

33 M. Ivanova, S. Sievers, M. Sawaya, J. Wall and D. Eisenberg, Proc. Natl. Acad. Sci. U. S. A., 2009, 106, 18990-18995.

34 M. Ivanova, M. Thompson and D. Eisenberg, Proc. Natl. Acad. Sci. U. S. A., 2006, 103, 4079-4082.

35 D. J. Lindberg, M. S. Wranne, M. G. Gatty, F. Westerlund and E. K. Esbjörner, Biochem. Biophys. Res. Commun., 2015, 458, 418-423.

36 D. Chergui, M. Hamdi, M. Baboulene, V. Speziale and A. Lattes, J. Heterocycl. Chem., 1986, 23, 1721-1724.

37 L. Felau and L. R. Brown, Anal. Biochem., 2006, 353, 144-146. 38 V. Uversky and A. Fink, Biochim. Biophys. Acta, 2004, 1698, 131-153. 